\title{
FACTORS DETERMINING SURVIVABILITY TRAITS OF CHAROLLAIS, KENT LAMBS, AND THEIR CROSSBREDS DURING REARING
}

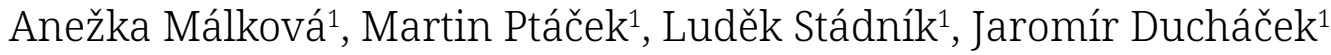 \\ ${ }^{1}$ Department of Animal Science, Faculty of Agrobiology, Food and Natural Resources, Czech University of Life \\ Sciences Prague, Kamýcká 129, 165 00, Prague 6 - Suchdol, Czech Republic
}

Link to this article: https://doi.org/10.11118/actaun202068030539

Received: 9. 4. 2020, Accepted: 19. 5. 2020

To cite this article: MÁLKOVÁ ANEŽKA, PTÁČEK MARTIN, STÁDNÍK LUDĚK, DUCHÁČEK JAROMÍR. 2020. Factors Determining Survivability Traits of Charollais, Kent Lambs, and their Crossbreds During Rearing. Acta Universitatis Agriculturae et Silviculturae Mendelianae Brunensis, 68(3): 539-549.

\begin{abstract}
The aim of this work was to evaluate the effect of birth weight on the survival of Charollais, Kent and their crossbreds in breeding and also on their meat performance for Charollais and Kent lambs. Data were evaluated for the six years period in the commercial flock. The total number of lambs used for evaluation was 1,197. The data were passed through the SAS STAT program using the MIXED method. In the model equation, all the dependent variables of the survival indicator were significantly statistically detectable with a significance level of $\mathrm{P}<0.01$. The results indicated that survivability lambs was significantly influenced by birth weight and litter size $(\mathrm{P}<0.05)$. Meat performance of lambs was affected the most combined year and month, breed and litter size $(\mathrm{P}<0.05)$. The results suggest better survivability abilities for the crossbred than the pure-bred population. Despite the lack of meat performance data, it is interesting to consider a possible selection program for the breeds, Charollais and Kent, to improve the survival of lambs for extending extensive farming methods. However, also by improving flock management we will achieve better survivability results for lambs.
\end{abstract}

Keywords: survivability, growth ability, birth weight, Charollais, Kent, crossbreds

\section{INTRODUCTION}

Production of healthy and strong lambs in optimal slaughter weight determinates an effective sheep farming management. Contrary, the lambs losses have an adversed effect on the breeding profitability, or genetic gain in the flock. Improvement can be achieved by animals selection, flock management modification, and reducing the risk factors for lamb mortality (Vostrý and Milerski, 2013; Getachew et al., 2015). Wolfová et al. (2009) estimated the economic loss at 2.1 euros per year per ewe; so the profit is in negative numbers without government subsidies. Their study shows a significant impact of lamb survivability, litter size and growth characteristics on the overall sustainability of breeding. Optimizing survivability traits is important in generally preffered extensive sheep farming with minimal inputs. This offers a possibility of crossing extensive breeds (mostly Kent: 3,127 ewes, and Sumava: 2,425 ewes according to official statistics; Bucek et al., 2019) in maternal position with intensive meat purpose breeds (mostly Suffolk: 4,245 ewes; Texel: 1,034 ewes, and Charollais: 403 ewes according to official statistics; Bucek et al., 2019) in terminal sire positions for finishing lambs production. In this sense the Charollais sheep shows a regular decrease across previous years; however, potential for lambs survivability should be in particular interest in its potential wider use with regards to prime finishing lambs production. 
Heritability of overall lamb survival is around $0.28-0.39$ and gradually decreases to 0.08 with the age of lamb (Riggio et al., 2008; Cloete et al., 2009). This offers a potential success on animal selection for these traits as to reduce the number of dead lambs. Above genetic predisposition, the lambs survivability is influenced by other genetic and non-genetic factors, such as breed (Mousa-Balabel, 2010), age of ewe (Aktaş et al., 2015), litter size (Ptáček et al., 2017), sex (Hatcher et al., 2009; Getachew et al., 2015), or birth weight (Ptáček et al., 2017). The importance of birth weight related to survivability traits confirmed previous studies (Greenwood et al., 2002; Thomson et al., 2004; Casellas et al., 2007; Schreurs et al., 2010) performed on Kent, Ripollesa, Merino breeds and their crossbreds or Suffolk crossbreds.

Above survivability and successful rearing of the lambs, the farms profits in meat flocks is also determined by lambs meat performance. Knowning, importance factors influencing the growth capacity of lambs, these traits are affected by lambs birth weight (Štolc et al., 2011; Ptáček et al., 2013; Aktaş and Doğan, 2014; Ptáček et al., 2015; Ptáček et al., 2017; Janoš et al., 2018). These are one of many factors that have a major impact on meat yields, and by monitoring and optimizing it is possible to achieve better rearing results and subsequent meat production (Çelik and Yilmaz, 2010).

The aim of this work is to monitor survivability traits in Charollais, Kent lambs and their crossbreds. Another aim was to determine the optimal birth weight for Charollais, Kent and their crossbreds with respect to subsequent survivability indicators, or meat performance respectively.

\section{MATERIALS AND METHODS}

\section{Flock Management}

The monitoring was carried out at a commercial meat sheep flock (Charollais, Kent, and their crossbreds) located at the Plzeň-sever district, Czech Republic (GPS - 49.9566583N, 13.1566792E, average annual temperature $-8.4{ }^{\circ} \mathrm{C}$, average annual precipitation - 550-650 $\mathrm{mm}$, inclination - moderate, $3-7^{\circ} \mathrm{C}$ ). In the grazing season (from April to mid-October), the main sheep nutritional requirements were provided by grazing pasture, with predominant grasses and clover species: Lolium perenne, Festuca pratensis, Festuca rubra, Poa pratensis, and Trifolium repens and Trifolium pratense. The pasture management was realized as rotational pasture with the maximum stocking rate of 3-4 livestock units per hectare in particular plots. Sheep had access to a light prefabricated canvas stable, ad libitum access to water, salt mineral licks and hay. In the non-grazing season (mid-October to April), the animals were housed in a brick sheepfolds and their feeding ration was composed of hay (ad libitum) and silage (3-5 kg). Additionally, feeding ration of pregnant and nursing ewes was enriched for molasses (50 ml per ewe per day) and extra mineral licks (Star Bloc BEBIGEST, MIKROP). All animals had ad libitum access to drinking water, hay, and mineral licks during the whole year. Lambs feeding ration was composed of ad libitum mother's milk, grassland pasture, hay (ad libitum) and concentrated feed in the average amount of 200 grams per head per day. The breeding season takes place using natural breeding from November to January. Lambing takes place from March to the first half of May in the sheepfold. After birth, the sheep were separated into the lambing pens for one to two days and then, after marking the lambs with ear tags, transferred to nurseries of about 10-12 ewes. In good climatic conditions, they were released to grazing pasture after 7-14 days of age.

\section{Data Collection}

The flock analysis included 1,197 Charollais, Kent and their crossbreds monitored over a six years period (2013-2018). Immediately after birth all lambs (dead and live) were weighed (BW, kg). All lamb losses were recorded across the period of their rearing (till 100 day of age), for estimation of parameters of live born lambs (LB, \%), lambs weaned at 72 hours (WEAN72, \%), lambs weaned at 14 days (WEAN14, \%), and lambs weaned at 100 days (WEAN100, \%).

In pure-bred populations of Charollais and Kent lambs the collected data were added about the lambs live weight at 100 days of age (LW100, kg), (Milerski, 2005), dorsal muscle depth (musculus longisimus lumborum et thoracis) at 100 days (MLLT100, mm) and subcutaneous backfat thickness at 100 days (BT100, mm), (Milerski, 2007). MLLT100 and BT100 were measured by ultrasound and $5 \mathrm{MHz}$ linear probe behind the area of last rib arch. Average daily gain at 100 days (ADG100, g) was calculated according to the formula:

$\mathrm{ADG} 100=[(\mathrm{LW} 100-\mathrm{BW}) / 100] \times 1000$.

Additionally, information about year of lambing, ewes age, sex of lambs, litter size, and lambing season were obtained from the farm's records.

\section{Statistical Evaluation}

Statistical analyses were performed in the statistical program SAS STAT, MIXED procedure. For evaluation of dependent variables live-born lambs, rearing up to 72 hours, rearing up to 14 days, rearing up to 100 days lamb age - the followed model equation was used. Results were visualized in forms of figures by MS Excell software.

$$
\begin{aligned}
& \mathrm{Y}_{\mathrm{ijk} k \mathrm{lmn}}=\mu+\text { Year }- \text { Season }+ \text { Breed }_{\mathrm{i}}+\text { Age }_{\mathrm{j}}+\operatorname{SeX}_{\mathrm{k}}+ \\
& + \text { Litter size }_{1}+\text { Birth weight }_{m}+\mathrm{e}_{\mathrm{ijkkmn}} \text {. } \\
& \mathrm{Y}_{\mathrm{ijk} \mathrm{kmn}} \text {...................dependent variable (LB, WEAN72, } \\
& \text { WEAN14, WEAN100); }
\end{aligned}
$$


Year-Season..combined randomized year seasonal effect (1-9 levels);

Breed................fixed effect of breed $(\mathrm{i}=$ Charollais, $\mathrm{n}=729$; $\mathrm{i}=$ Kent, $\mathrm{n}=220$; $\mathrm{i}=$ Kent $\mathrm{x}$ Charollais crossbreds, $n=257$ );

Age ....................fixed effect of ewe's age ( $\mathrm{j}=1$-year old and 2-year ewes, $n=271 ; j=3$-year old ewes, $n=314 ; j$ = 4-year old ewes, $\mathrm{n}=267 ; \mathrm{j}=5$-year ewes, $\mathrm{n}=169$; $\mathrm{j}=6$-year-old ewes, $n=106 ; j$ = 7-yearold and ewes, $n=109$ );

Lamb sex........fixed effect of lamb sex $(\mathrm{k}=$ males, $\mathrm{n}=603$; $\mathrm{k}$ = females, $\mathrm{n}=631$ );

Litter size .......fixed effect of litter size $(1=$ singles, $\mathrm{n}=277$; $\mathrm{l}$ = twins, $\mathrm{n}=878 ; \mathrm{l}=$ triplets, $\mathrm{n}=81$ );

Birth weight..fixed effect of lambs birth weight $(\mathrm{m}=$ birth weight $0.5-1 \mathrm{~kg}, \mathrm{n}=83$; $\mathrm{m}=$ birth weight 1-2 kg, $\mathrm{n}=89$; $\mathrm{m}=$ birth weight $2-3 \mathrm{~kg}, \mathrm{n}=395$; $\mathrm{m}=$ birth weight $3-4 \mathrm{~kg}, \mathrm{n}=242$; $\mathrm{m}=$ birth weight $4-5 \mathrm{~kg}, \mathrm{n}=208$; $\mathrm{m}=$ birth weight $5-6 \mathrm{~kg}, \mathrm{n}=79$; $\mathrm{m}=$ birth weight 6-7 kg; $\mathrm{n}=131$ );

$\mathrm{e}_{\mathrm{ijklmn}} \ldots . . . . . . . . . . . . . . . \mathrm{residual}$ error.

The same statistical model, however, with different number of observation in particular classes was applied for meat performance characteristics analysis (live weight at 100 days of age, daily gain from birth till 100 days of age, MLLT depth and fat thickness lambs):

$$
\begin{aligned}
\mathrm{Y}_{\mathrm{ijklmn}}= & \mu+\text { Year }- \text { Season }+ \text { Breed }_{\mathrm{i}}+\text { Age }_{\mathrm{j}}+\text { Sex }_{\mathrm{k}}+ \\
& + \text { Litter size }_{1}+\text { Birth weight }_{\mathrm{m}}+\mathrm{e}_{\mathrm{ijklmn}} .
\end{aligned}
$$

$\mathrm{Y}_{\mathrm{ijklmn}}$ ……...........dependent variable (ADG100, LW100, MLLT100, BT100);

Year-Season..combined randomized year seasonal effect (1-9 levels);
Breed. ...fixed effect of breed $(\mathrm{i}=$ Charollais, $n=729 ; \mathrm{i}=$ Kent, $\mathrm{n}=220$ );

Age ...................fixed effect of ewe's age $(\mathrm{j}=1$-year old and 2-year ewes, $\mathrm{n}=271$; $\mathrm{j}=3$-year old ewes, $n=314 ; j=4$-year old ewes, $n=267$; $\mathrm{j}$ = 5-year ewes, $n=169$; $\mathrm{j}=$ 6-year-old ewes, $\mathrm{n}=106 ; \mathrm{j}$ = 7-year-old and ewes, $\mathrm{n}=109)$;

Lamb sex........fixed effect of lamb sex $(\mathrm{k}=$ males, $n=603 ; \mathrm{k}$ = females, $\mathrm{n}=631$ );

Litter size .......fixed effect of litter size $(l=$ singles, $\mathrm{n}=277 ; \mathrm{l}=$ twins, $\mathrm{n}=878 ; \mathrm{l}=$ triplets, $\mathrm{n}=81$ );

Birth weight..fixed effect of lambs birth weight $(\mathrm{m}=$ birth weight $0.5-1 \mathrm{~kg}, \mathrm{n}=83$; $\mathrm{m}=$ birth weight 1-2 kg, $\mathrm{n}=89$; $\mathrm{m}=$ birth weight 2-3 kg, $\mathrm{n}=395$; $\mathrm{m}=$ birth weight 3-4 kg, $\mathrm{n}=242$; $\mathrm{m}=$ birth weight 4-5 kg, $\mathrm{n}=208$; $\mathrm{m}=$ birth weight 5-6 kg, $\mathrm{n}=79$; $\mathrm{m}=$ birth weight 6-7 kg; $\mathrm{n}=131$ ),

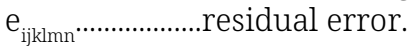

Differences between variables were estimated by the Tukey-Kramer test at significance level of $\mathrm{P}<0.05$.

\section{RESULTS}

\section{Model Description}

Litter size and birth weight were major factors influencing lambs survivability traits as reported in Tab. I. Some support for significance (significant or close to significant) was also detected for ewe age category. Model for WEAN100 was significant also for factors of breed and sex of lambs above mentioned factors. Additionally, Tab. I shows in detail significance of evaluated factors for meat performance characteristics in purebred lambs population.

I: Effects influences on survivability and meat performance of lambs

\begin{tabular}{lcccccc}
\hline \multicolumn{1}{c}{ Parameters } & YEAR-MONTH & BREED & LS & SEX & AGE & BW0 \\
\hline LIVE & NS & NS & $* * *$ & NS & NS & $* * *$ \\
WEAN72 & NS & NS & $* * *$ & NS & 0.059 & $* * *$ \\
WEAN14 & NS & NS & $* * *$ & NS & $*$ & $* * *$ \\
WEAN100 & NS & $* *$ & 0.08 & $*$ & 0.08 & $* * *$ \\
\hline LW100 & $* * *$ & $* * *$ & $* * *$ & $* * * * *$ & $* * *$ \\
MLLT100 & $* * *$ & $* * *$ & $* * *$ & NS & $*$ & NS \\
BT100 & $* * *$ & NS & $* *$ & NS & NS & NS \\
ADG100 & $* * *$ & $* * *$ & $* * *$ & $* * *$ & $* * *$ & NS \\
\hline
\end{tabular}

${ }^{*} \mathrm{P}<0.05 ;{ }^{* *} \mathrm{P}<0.01 ;{ }^{* * *} \mathrm{P}<0.001$; NS - non significant

YEAR-MONTH - combined randomized year seasonal effect; BREED - breed of lambs; LS - litter size; SEX - sex of lambs; AGE - ewe's age; BW0 - birth weight; LB - live born lambs (\%); WEAN72 - percentage of lambs weaned at 72 hours; WEAN14 - percentage of lambs weaned at 14 days; WEAN100 - percentage of lambs weaned at 100 days; LW100 lambs live weight at 100 days of age; MLLT100 - MLLT (musculus longisimus lumborum et thoracis) depth at 100 days of age; BT100 - subcutaneous backfat thickness at 100 days; ADG100 - average daily gain at 100 days of age 


\section{Survivability Analysis}

Fig. 1 shows lambs survivability traits in relation to lambs BW. Significantly lowest survivability was detected in lambs with a BW of $0.5-1 \mathrm{~kg}$ during the whole trial. This supported significant differences detected for these lambs in comparison to the all others evaluated groups concerning LB, WEAN72, and WEAN14 traits. Lambs with BW 1.1-2.0 kg reached similar survivability in comparison with heavier contemporaries during LB, and WEAN72; however, a noticeable significant decrease was noticed in WEAN14, and WEAN100 especially. On the end of the rearing period these lambs reached practically same survivability as did the lightness lambs with BW $0.5-1.0 \mathrm{~kg}$. Exactly these two groups differed significantly at the end to all the heavier lambs. In general, the highest survivability of the lambs was observed in lambs weighing $4.1 \mathrm{~kg}$ and more. Their survivability was higher than 93\% in all the monitored parameters ( $\mathrm{P}<0.001$ ), and these lambs did not differ mutually in their survivability during the whole rearing period.

Other evaluated factors contributing to survivability can be found in Figs. 2-5 in detail. Significantly lowest LB, WEAN72, and WEAN14 was demonstrated for singles in comparison with multiple litters, however the difference overlapped with WEAN100. Contrary, opposed shape was demonstrated for sex of lambs when same results between sexes were demonstrated for LB, WEAN72, and WEAN14. Significant 4\% decrease was demonstrated for males compared to females in WEAN100. Additionally, no significant differences were detected in lambs survivability in relation to ewe's age during the whole trial. Positive effect of crossbreds was demonstrating at the end of the rearing period (WEAN100) when these lambs differed significantly with both pure-bred Charollais (+ 9.7\%) and Kent lambs (+ 8.1\%) populations.
Till this time similar lambs survivability were demonstrated for all threes lambs populations, despite of nonsignificantly lowest survivability in Charollais lambs.

\section{Growth Analysis}

BW0 influenced only LW100 from all the evaluated meat performance characteristics. Significantly lowest LW100 was detected for lambs with a BW0 1.1-2 kg (25.87 kg). Significant differences were detected between these lambs and those in groups BW0 3.1-4 kg (28.38 kg), BW0 4.1-5 kg (29.11 kg), BW0 5.1-6 kg (29.62 kg) and BW0 $6.1-7 \mathrm{~kg}(30.48 \mathrm{~kg})$. Additionally, the highest LW100 (30.48 kg) had lambs with a birth weight of $6.1-7 \mathrm{~kg}$. The difference between the lambs weighing 1.1-2 kg and 6.1-7 kg was $4.6 \mathrm{~kg}(\mathrm{P}<0.05)$.

Tab. II shows the effects on the growth parameters of lambs. Significantly heigher ADG100 (+ 43.5-72.16 g), LW100 (+ 4.4-7.28 kg), MLLT100 $(+2.44-4.08 \mathrm{~mm})$, and BT100 (+ 0.63-0.84 mm) were observed in singles higher than in twins and triplets $(\mathrm{P}<0.05)$, where triplets were significantly slower in terms of growth. In addition, a significant difference between males and females was found for indicators ADG100 and LW100 (P < 0.05); males had $22.8 \mathrm{~g}$ higher ADG100 and $2.3 \mathrm{~kg}$ higher LW100 than females.

The best results were achieved in lambs from 4 years old ewes (ADG100 $263.94 \mathrm{~g}$, LW100 $29.94 \mathrm{~kg}$, MLLT100 24.28 mm; P < 0.05). Lambs from 3-yearold ewes also had good results over 1-2-year-old ewes. Overall, 1 to 2-year-old ewes had a negative impact on the lamb's meat performance.

Charollais lambs had the best meat performance characteristics in general. This concerned all the evaluated traits, and thus higher ADG100 by $53.2 \mathrm{~g}$, LW100 by $5.3 \mathrm{~kg}$ and MLLT100 by $4.7 \mathrm{~mm}(\mathrm{P}<0.05)$ than Kent lambs.

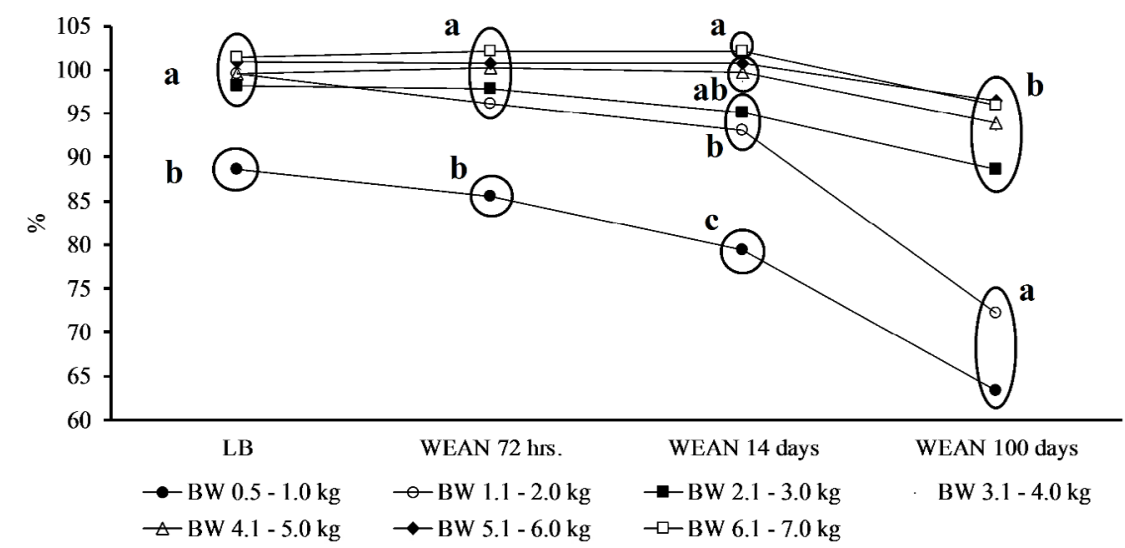

1: Effect of birth weight on survivability traits lambs (LSM values)

$\mathrm{a}, \mathrm{b}, \mathrm{c}$ - different letters among circled means within individual traits (within column) indicate statistical significance at $\mathrm{P}<0.05$ level;

LB - live born lambs (\%); WEAN 72 hrs. - percentage of lambs weaned at 72 hours (\%); WEAN 14 days -percentage of lambs weaned at 14 days (\%); WEAN 100 days - percentage of lambs weaned at 100 days (\%); BW - birth weight lambs (kg) 




2: Effect of breed on survivability traits lambs (LSM values)

$\mathrm{a}, \mathrm{b}$ - different letters among circled means within individual traits (within column) indicate statistical significance at $\mathrm{P}<0.05$ level;

LB - live born lambs (\%); WEAN 72 hrs. - percentage of lambs weaned at 72 hours (\%); WEAN 14 days - percentage of lambs weaned at 14 days (\%); WEAN 100 days - percentage of lambs weaned at 100 days (\%)



3: Effect of litter size on survivability traits lambs (LSM values)

$\mathrm{a}, \mathrm{b}$ - different letters among circled means within individual traits (within column) indicate statistical significance at $\mathrm{P}<0.05$ level;

LB - live born lambs (\%); WEAN $72 \mathrm{hrs}$. - percentage of lambs weaned at 72 hours (\%); WEAN 14 days - percentage of lambs weaned at 14 days (\%); WEAN 100 days - percentage of lambs weaned at 100 days (\%)



4: Effect of sex on survivability traits lambs (LSM values)

$\mathrm{a}, \mathrm{b}$ - different letters among circled means within individual traits (within column) indicate statistical significance at $\mathrm{P}<0.05$ level;

LB - live born lambs (\%); WEAN 72 hrs. - percentage of lambs weaned at 72 hours (\%); WEAN 14 days - percentage of lambs weaned at 14 days (\%); WEAN 100 days percentage of lambs weaned at 100 days (\%) 




5: Effect of age of ewe on survivability traits lambs (LSM values)

$\mathrm{a}, \mathrm{b}$ - different letters among circled means within individual traits (within column) indicate statistical significance at $\mathrm{P}<0.05$ level;

LB - live born lambs (\%); WEAN 72 hrs. - percentage of lambs weaned at 72 hours

(\%); WEAN 14 days - percentage of lambs weaned at 14 days (\%); WEAN 100 days percentage of lambs weaned at 100 days (\%)

II: Effect of selected factors on meat performance

\begin{tabular}{|c|c|c|c|c|}
\hline & ADG100 & LW100 & MLLT100 & BT100 \\
\hline & $\mathrm{LSM} \pm \mathrm{SELSM}$ & $\mathrm{LSM} \pm \mathrm{SELSM}$ & $\mathrm{LSM} \pm \mathrm{SELSM}$ & $\mathrm{LSM} \pm \mathrm{SELSM}$ \\
\hline \multicolumn{5}{|c|}{ Breed } \\
\hline $\mathrm{CH}$ & $275.98 \pm 4.111^{\mathrm{a}}$ & $31.12 \pm 0.411^{\mathrm{a}}$ & $25.89 \pm 0.339^{a}$ & $3.46 \pm 0.171^{\mathrm{a}}$ \\
\hline$\underline{\mathrm{K}}$ & $222.77 \pm 5.024^{b}$ & $25.81 \pm 0.502^{b}$ & $21.22 \pm 0.432^{\mathrm{b}}$ & $3.42 \pm 0.218^{\mathrm{a}}$ \\
\hline \multicolumn{5}{|c|}{ Litter size } \\
\hline Single & $287.93 \pm 4.656^{\mathrm{a}}$ & $32.36 \pm 0.466^{\mathrm{a}}$ & $25.73 \pm 0.392^{\mathrm{a}}$ & $3.93 \pm 0.198^{a}$ \\
\hline Twins & $244.42 \pm 3.307^{b}$ & $27.96 \pm 0.331^{b}$ & $23.29 \pm 0.287^{b}$ & $3.30 \pm 0.145^{\mathrm{b}}$ \\
\hline Triplets & $215.77 \pm 7.846^{c}$ & $25.08 \pm 0.785^{c}$ & $21.65 \pm 0.638^{c}$ & $3.09 \pm 0.321^{b}$ \\
\hline \multicolumn{5}{|c|}{ Sex } \\
\hline Male & $260.75 \pm 4.143^{\mathrm{a}}$ & $29.61 \pm 0.414^{\mathrm{a}}$ & $23.52 \pm 0.348^{\mathrm{a}}$ & $3.36 \pm 0.175^{a}$ \\
\hline$\underline{\text { Female }}$ & $238 \pm 4.121^{\mathrm{b}}$ & $27.33 \pm 0.412^{\mathrm{b}}$ & $23.60 \pm 0.351^{\mathrm{a}}$ & $3.52 \pm 0.177^{\mathrm{a}}$ \\
\hline \multicolumn{5}{|c|}{ Ewe age } \\
\hline 1-2 year & $237.34 \pm 5.41^{\mathrm{a}}$ & $27.24 \pm 0.541^{\mathrm{a}}$ & $22.64 \pm 0.452^{\mathrm{a}}$ & $3.45 \pm 0.228^{a}$ \\
\hline 3 year & $254.88 \pm 4.405^{\mathrm{b}}$ & $29.01 \pm 0.441^{b}$ & $23.95 \pm 0.376^{b}$ & $3.67 \pm 0.189^{a}$ \\
\hline 4 year & $263.94 \pm 4.738^{b}$ & $29.94 \pm 0.474^{b}$ & $24.28 \pm 0.403^{b}$ & $3.59 \pm 0.203^{a}$ \\
\hline 5 year & $246.94 \pm 6.170^{\mathrm{ab}}$ & $28.26 \pm 0.617^{a b}$ & $23.50 \pm 0.516^{\mathrm{ab}}$ & $3.51 \pm 0.260^{\mathrm{a}}$ \\
\hline 6 year & $250.73 \pm 7.887^{\mathrm{ab}}$ & $28.58 \pm 0.789^{\mathrm{ab}}$ & $23.71 \pm 0.655^{\mathrm{ab}}$ & $3.26 \pm 0.330^{\mathrm{a}}$ \\
\hline 7 and more year & $242.41 \pm 8.088^{\mathrm{ab}}$ & $27.78 \pm 0.809^{\mathrm{ab}}$ & $23.26 \pm 0.681^{\mathrm{ab}}$ & $3.17 \pm 0.343^{\mathrm{a}}$ \\
\hline \multicolumn{5}{|c|}{ Birth Weight } \\
\hline $0.5-1 \mathrm{~kg}$ & $255.94 \pm 9.991^{\mathrm{a}}$ & $27.61 \pm 0.999 \mathrm{abc}$ & $23.36 \pm 0.819^{a}$ & $3.17 \pm 0.412^{\mathrm{a}}$ \\
\hline $1.1-2 \mathrm{~kg}$ & $233.58 \pm 8.228^{a}$ & $25.87 \pm 0.823^{\mathrm{a}}$ & $22.73 \pm 0.693^{\mathrm{a}}$ & $3.73 \pm 0.349^{a}$ \\
\hline $2.1-3 \mathrm{~kg}$ & $251.95 \pm 4.481^{\mathrm{a}}$ & $28.21 \pm 0.448^{\mathrm{ab}}$ & $23.72 \pm 0.382^{\mathrm{a}}$ & $3.36 \pm 0.192^{\mathrm{a}}$ \\
\hline $3.1-4 \mathrm{~kg}$ & $248.78 \pm 4.865^{\mathrm{a}}$ & $28.38 \pm 0.487^{b c}$ & $23.83 \pm 0.420^{\mathrm{a}}$ & $3.55 \pm 0.212^{\mathrm{a}}$ \\
\hline $4.1-5 \mathrm{~kg}$ & $251.09 \pm 5.513^{\mathrm{a}}$ & $29.11 \pm 0.551^{\mathrm{bc}}$ & $23.93 \pm 0.463^{\mathrm{a}}$ & $3.33 \pm 0.233^{\mathrm{a}}$ \\
\hline $5.1-6 \mathrm{~kg}$ & $251.52 \pm 7.411^{\mathrm{a}}$ & $29.62 \pm 0.741^{\mathrm{bc}}$ & $23.26 \pm 0.607^{\mathrm{a}}$ & $3.76 \pm 0.306^{a}$ \\
\hline $6.1-7 \mathrm{~kg}$ & $252.77 \pm 7.018^{\mathrm{a}}$ & $30.48 \pm 0.702^{c}$ & $24.07 \pm 0.570^{\mathrm{a}}$ & $3.17 \pm 0.287^{\mathrm{a}}$ \\
\hline
\end{tabular}

a, b, c - different letters within columns for individual traits means statistical significance at $\mathrm{P}<0.05$ level;

ADG100 - average daily gain at 100 days of age; LW100 - lambs weight at 100 days of age; MLLT100 - MLLT (musculus longisimus lumborum et thoracis) depth at 100 days of age; BT100 - subcutaneous backfat thickness at 100 days; $\mathrm{CH}$ - Charollais lambs; K - Kent lambs 


\section{DISCUSSION}

\section{Survivability Analysis}

This article describes not only the survival of lambs in rearing, but also their subsequent meat performance in Charollais, Kent and their crossbreeds. Survivability is associated not only with the growth characteristics of lambs; therefore, this issue should be addressed comprehensively. In general, breeders are largely neglected to record data on childbirth and the postpartum period. Over the past 40 years, there have been no significant changes in the survival of lambs and the average mortality rate is around 15\% (Dwyer et al., 2015). Therefore, relationships between survivability of lambs, or their meat performance and factors that influence them should be, as far as possible applied to the flock management, or scientific knowledge, in a simply form easy to understand.

The results show that survivability affected most the examined indicators. The major influence was found in the birth weight, which had a significant effect on the whole monitored rearing period. Optimal birth weight exceeding $4 \mathrm{~kg}$ was determined for the evaluated lambs in their typical flock conditions. These lambs had much higher chance to survive till weaning than lambs with a lower birth weight. Riggio et al. (2008) reported in their study that survival is positively correlated with the birth weight of lambs. However, the question arises as to whether the mortality of the lambs is due to the birth weight factor itself or whether the rearing method already plays a more important role. For example, the effect of hypothermia is most threatening in the first 5 days after birth. Rationale for our decline survivability after 3 days after birth such as injury, illness, nutrition or other flock problems (Plush et al., 2016). Weak lambs, low birth weight, despite sufficient milk intake, increase the possibility of mortality (Nash et al., 1996). Abdelqader et al. (2017) reported in their research that the difficulty of childbirth caused lambs losses. Most of the lambs after a difficult childbirth died a few days after birth. Also, lambs that died after difficult labor were $2.1 \times$ heavier from the average birth weight of the lambs and with 1.6× higher mortality in male lambs. However, lambs with a higher birth weight were favoured and achieved better results than lambs with a birth weight below $3 \mathrm{~kg}$. Other results were also achieved by Gowane et al. (2018) who found higher mortality of lambs with birth weight below $2 \mathrm{~kg}$.

Litter size, as an important factor in the rearing of lambs, had a significant impact on survivability of lambs. Multiple litters strongly exceeded the survivability singles within 14 days of age in lambs. Significant differences were found between singles and triplets in rearing up to 72 hours and 14 days of lamb age. Similar results in weaned lambs were achieved by Turkson and Sualisu (2005), Holmøy et al. (2014) and Ptáček et al. (2017). By contrast, Mousa-Balabel (2010), Gavojdian et al. (2012) and Getachew et al. (2015) in their research reported opposed result. The low survival of lambs from multiple litters is usually explained by the low birth weight as compared to the singles; however, birth weight was part of our model, so our low survivability detected in singles can be caused by complicated labors that Dalton et al. (1980) and Holmøy et al. (2014) have reported.

In this study, the sex of the lambs was reflected in the survival of the lambs so that males were more likely to die than female lambs, however, significant support for this thesis was obvious after $14^{\text {th }}$ day of age. The same results were obtained by Riggio et al. (2008) and Abdelqader et al. (2017). Survivability decrease be connected with flock management, when lambs at approx. 14 days after birth were moved from brick sheepfolds to pasture with their mothers (Everett-Hincks et al., 2005). Ferreira et al. (2015) in their study reported that females within 1 day of age had a lower survivability than males, but then before and after weaning had a higher survivability.

Lambs from 2-year-old ewes had the highest survivability. Additionally, also older ewes (over 6 years of age) can be used successfully in reproduction under conditions of the evaluated flock as survivability of their lamb does not significantly decrease. This is in some controversion with previously published results of Knight et al. (1988), Thomson et al. (2004) or Aktaş et al. (2015).

The survivability up to 100 days was influenced by genetic predisposition, when significantly the best results were detected in Charollais $x$ Kent crossbreds. Positive effect of crossbreeding was largely confirmed by Gamma et al. (1991) Thomson et al. (2004), Kutluca Korkmaz and Emsen (2018) and Freking and Bennett (2019) who reported that the crossing had a demonstrable effect on the survivability of lambs. Charollais sheep is generally considered as sensitive breed prone to lambs deaths during rearing (Dwyer and Lawrence, 2005). Anyway, this potential disadvantage was effectively suppressed by crossing with Kent breed, very resistant sheep breed suitable for all-year outdoor breeding systems (Knight et al., 1988). Higher survivability of crossbred lambs supported by significant difference, confirmed this assumption. On the contrary, Elizalde et al. (2019) found better survivability of purebred lambs of the breed Corriedale over crossbreeds with Texel, Dorset and Suffolk ram.

\section{Growth Analysis}

The birth weight of the lambs influenced live weight, when lambs heavier than $4.1 \mathrm{~kg}$ showed higher LW100 over lighter contemporaries. Contrary, lambs weighing up to $2 \mathrm{~kg}$ demonstrated the worst results in general. The lambs that had 
a higher birth weight were mostly singles, males and lambs from ewes with better condition and better nutrition. Therefore, it is essential to achieve optimal birth weights for lambs to attain faster slaughter weight. Moreover, higher survivability of heavier lambs, was detected, despite the possible increase in difficult births (Thomson et al., 2004; Sušić et al., 2005).

Significantly faster growth intensity of single lambs compared to those from multiple litters (Dixit et al., 2001; Ptáček et al., 2013) was demonstrated in our study as well. Similarly better growth ability of males were previously confirmed by Momani Shaker et al. (2010), Taskin et al. (2012), Simeonov et al. (2014) and Ghafouri-Kesbi and Notter (2016). Differences between the sexes may be due to the different configuration and muscle growth of females and male lambs. The male lambs deposit more of their muscle mass in the chest area than in the dorsal area where ultrasonography is performed (Milerski et al., 2006). The effect of lamb sex is also reported by Burfening and Carpio (1993); El Fadili et al. (2000); Peña et al. (2005); Kuchtík and Dobeš (2006); Hošek et al. (2008); Rashidi et al. (2008); Štolc et al. (2011) and Rahimi et al. (2014). Ewes 1-2 years old had in our study significant negative effect on the meat performance of lambs. The best results were achieved in lambs from 3-4 years old ewes, but with good survivability and meat performance, ewes over 6 years of age may also be well-suited.
Similar results were obtained by Dixit et al. (2001) and Baneh and Hafezian (2009).

Further monitoring was performed to obtain data for evaluating the meat performance of Charollais and Kent breed. The growth of lambs was influenced by genotype, when Charollais lambs reached significantly better results than Kent reared under identical breeding conditions. This performance is largely due to the focus of the breed's performance. Genes of certain breeds have the ability to improve the overall performance of animals (Paim et al., 2013). The influence of breeding affiliation is also documented by Ptáček et al. (2011) and de Vargas Junior et al. (2014). Paim et al. (2013) reported in their study that purebred animals of the Ile de France breed had the same growth capabilities or higher than crossbreds with other meat breeds. The influence of breed Charollais and its crossbreds was describe by Petr et al. (2009) in our conditions. Otherwise, Charollais and Kent are mostly kept in pure form in the Czech Republic, and their crossing is not so common (Bucek et al., 2019). Disposition of our study did not allow this interesting crossing between these breeds. However, comparing both purebred populations in our results indicated on potentially improved meat performance in crossbreds over Kent. In context of previously demonstrated survivability traits our results indicate on perspective hybrid combination applicated under extensive production systems in the Czech Republic.

\section{CONCLUSION}

Effects of birth weight, ewe age, litter size, sex and breed on survivability and growth indicators in Charollais, Kent and their crossbreds, were studied in this study. Birth weight was one of the main driving factors affecting the survivability lambs throughout their rearing. Its influence was observed followed by growth of lambs, especially for live weight. The birth weight from 4 to $7 \mathrm{~kg}$ was estimated to be most beneficial. Unfortunately, crossbreds were not available for subsequent analysis of growth abilities. However, confrontation of purebred populations clearly shows better indicators of meat performance for Charollais breed over Kent lambs. In combination with the survivability evaluation, where results of survivability traits were even better compared to the generally respected resistant Kent breed, the use of the Charollais breed looks perspective. The susceptibility of the pure-bred Charollais breed presented in some works can thus be eliminated using this crossing scheme. This study thus indicated some perspective tools of flock management for farmers breeding their sheep under extensive breeding conditions.

Acknowledgements

The study was supported from the "S" grant of MŠMT ČR.

\section{REFERENCES}

ABDELQADER, A., IRSHAID, R., TABBAA, M. J., ABUAJAMIEH, M., TITI, H. and AL-FATAFTAH, A. R. 2017. Factors influencing Awassi lambs survivorship under fields conditions. Livest. Sci., 199: 1-6. AKTAŞ, A. H. and DOǦAN, Ş. 2014. Effect of live weight and age of Akkaraman ewes at mating on multiple birth rate, growth traits, and survival rate of lambs. Turkish J. Vet. Anim. Sci., 38(2): 176-182.

AKTAŞ, A. H., DURSUN, S., DOGAN, S., KIYMA, Z., DEMIRCI, U. and HALICI, I. 2015. Effects of ewe live weight and age on reproductive performance, lamb growth, and survival in Central Anatolian Merino sheep. Arch. Anim. Breed., 58(2): 451-459. 
BANEH, H. and HAFEZIAN, S. H. 2009. Effects of environmental factors on growth traits in Ghezel sheep. Afr. J. Biotechnol., 8(12): 2903-2907.

BUCEK, P., KÖLBL, M., MILERSKI, M., PINĎÁK, A. and MAREŠ, V. 2019. Yearbook of Sheep and Goat Breeding in the Czech Republic in 2018 [in Czech: Ročenka chovu ovcí a koz v České republice za rok 2018]. Českomoravská společnost chovatelů, a. s., SCHOK v ČR.

BURFENING, P. J. and CARPIO, M. P. 1993. Genetic and environmental factors affecting growth rate and survival of Junin sheep in the central highlands of Peru. Small Rumin. Res., 11(3): 275-287.

CASELLAS, J., CAJA, G., SUCH, X. and PIEDRAFITA, J. 2007. Survival analysis from birth to slaughter of Ripollesa lambs under semi-intensive management. J. Anim. Sci., 85(2): 512-517.

ÇELIK, R. and YILMAZ, A. 2010. Certain meat quality characteristics of Awassi and Turkish Merino $\times$ Awassi ( $\mathrm{F}_{1}$ ) lambs. Turkish J. Vet. Anim. Sci., 34(4): 349-357.

CLOETE, S. W. P., MISZTAL, I. and OLIVIER, J. J. 2009. Genetic parameters and trends for lamb survival and birth weight in a Merino flock divergently selected for multiple rearing ability. J. Anim. Sci., 87(7): 2196-2208.

DALTON, D. C., KNIGHT, T. W. and JOHNSON, D. L. 1980. Lamb survival in sheep breeds on New Zealand hill country. New Zeal. J. Agric. Res., 23(2): 167-173.

DE VARGAS JUNIOR, F. M., MARTINS, C. F., DOS SANTOS PINTO, G., FERREIRA, M. B., DE ALMEIDA RICARDO, H., LEÃO, A. G., FERNANDES, A. R. M. and TEIXEIRA, A. 2014. The effect of sex and genotype on growth performance, feed efficiency, and carcass traits of local sheep group Pantaneiro and Texel or Santa Inês crossbred finished on feedlot. Trop. Anim. Health Prod., 46(5): 869-875.

DIXIT, S. P., DHILLON, J. S. and SINGH, G. 2001. Genetic and non-genetic parameter estimates for growth traits of Bharat Merino lambs. Small Rumin. Res., 42(2): 101-104.

DWYER, C. M. and LAWRENCE, A. B. 2005. A review of the behavioural and physiological adaptations of hill and lowland breeds of sheep that favour lamb survival. Appl. Anim. Behav. Sci., 92(3): 235260.

DWYER, C. M., CONINGTON, J., CORBIERE, F., HOLMOY, I. H., MURI, K., NOWAK, R., ROOKE, J., VIPOND, J. and GAUTIER, J. M. 2015. Invited review: Improving neonatal survival in small ruminants: Science into practice. Animal, 10(3): 449-459.

EL FADILI, M., MICHAUX, C., DETILLEUX, J. and LEROY, P. L. 2000. Genetic parameters for growth traits of the Moroccan Timahdit breed of sheep. Small Rumin. Res., 37(3): 203-208.

ELIZALDE, H. F., CARSON, A. F. and MUÑOZ, C. 2019. Effects of sire genotype on lamb performance at weaning in extensive sheep systems. Animal, 13(1): 213-220.

EVERETT-HINCKS, J. M., BLAIR, H. T., STAFFORD, K. J., LOPEZ-VILLALOBOS, N., KENYON, P. R. and MORRIS, S. T. 2005. The effect of pasture allowance fed to twin- and triplet-bearing ewes in late pregnancy on ewe and lamb behaviour and performance to weaning. Livest. Prod. Sci., 97(2-3): 253-266.

FERREIRA, V. C., ROSA, G. J. M., BERGER, Y. M. and THOMAS, D. L. 2015. Survival in crossbred lambs: Breed and heterosis effects. J. Anim. Sci., 93(3): 912-919.

FREKING, B. A. and BENNETT, G. L. 2019. Rambouillet and Romanov reciprocal breed effects on survival and growth traits of F1 lambs and on reproductive traits of F1 ewes. J. Anim. Sci., 97(2): 578-586.

GAMA, L. T., DICKERSON, G. E., YOUNG, L. D. and LEYMASTER, K. A. 1991. Effects of breed, heterosis, age of dam, litter size, and birth weight on lamb mortality. J. Anim. Sci., 69(7): 2727-2743.

GAVOJDIAN, D., CZISZTER, L. T., PADEANU, I., PACALA, N., ERINA, S., ILIE, D., SAUER, M. and TRIPON, I. 2012. Researches regarding growth rates, survivability and carcass quality in F1 Dorper x Turcana lambs reared extensively. J. Food, Agric. Environ., 10(2): 617-619.

GETACHEW, T., GIZAW, S., WURZINGER, M., HAILE, A., RISCHKOWSKY, B., OKEYO, A. M., SÖLKNER, J. and MÉSZÁROS, G. 2015. Survival analysis of genetic and non-genetic factors influencing ewe longevity and lamb survival of Ethiopian sheep breeds. Livest. Sci., 176: 22-32.

GHAFOURI-KESBI, F. and NOTTER, D. R. 2016. Sex influence on genetic expressions of early growth in Afshari lambs. Arch. Anim. Breed., 59(1): 9-17.

GOWANE, G. R., SWARNKAR, C. P., PRINCE, L. L. L. and KUMAR, A. 2018. Genetic parameters for neonatal mortality in lambs at semi-arid region of Rajasthan India. Livest. Sci., 210: 85-92.

GREENWOOD, P. L., HUNT, A. S., SLEPETIS, R. M., FINNERTY, K. D., ALSTON, C., BEERMANN, D. H. and BELL, A. W. 2002. Effects of birth weight and postnatal nutrition on neonatal sheep: III. Regulation of energy metabolism. J. Anim. Sci., 80(11): 2850-2861.

HATCHER, S., ATKINS, K. D. and SAFARI, E. 2009. Phenotypic aspects of lamb survival in Australian Merino sheep. J. Anim. Sci., 87(9): 2781-2790.

HOLMØY, I. H., WAAGE, S. and GRÖHN, Y. T. 2014. Ewe characteristics associated with neonatal loss in Norwegian sheep. Prev. Vet. Med., 114(3-4): 267-275. 
HOŠEK, M., KONEČNÁ, L., KUCHTÍK, J. and FILIPČÍK, R. 2008. Effect of breed, sex and litter size on growth and meatiness and fatiness in vivo in lambs. Acta Univ. Agric. Silvic. Mendelianae Brun., 56(4): 231-238.

JANOŠ, T., FILIPČÍK, R. and HOŠEK, M. 2018. Evaluation of growth intensity in Suffolk and Charollais sheep. Acta Univ. Agric. Silvic. Mendelianae Brun., 66(1): 61-67.

KNIGHT, T. W., LYNCH, P. R., HALL, D. R. H. and HOCKEY, H. U. P. 1988. Identification of factors contributing to the improved lamb survival in Marshall Romney sheep. New Zeal. J. Agric. Res., 31(3): 259-271.

KORKMAZ, M. K. and EMSEN, E. 2018. Comparison of Mutton Charollais Lambs and Their Cross Lambs Born from Indigenous Fat Tailed and F1 Prolific Breed Ewes. Turkish J. Agric. - Food Sci. Technol., 6(10): 1419.

KUCHTÍK, J. and DOBEŠ, I. 2006. Effect of some factors on growth of lambs from crossing between the Improved Wallachian and East Friesian. Czech J. Anim. Sci., 51(2): 54.

MILERSKI, M. 2005. Methodologies for estimating breeding values for sheep [in Czech: Metodika odhadu plemenných hodnot u ovcí]. Praha: VúŽV Uhříněves.

MILERSKI, M. 2007. Methodology of ultrasonic measurements of the conformation and fatness of lambs and kids [in Czech: Metodika provádění ultrazvukových měrení zmasilosti a protučnělosti jehňat a kůzlat]. Praha: VÚŽV Uhříněves.

MILERSKI, M., MARGETÍN, M. and MAXA, J. 2006. Factors affecting the longissimus dorsi muscle depth and backfat thickness measured by ultrasound technique in lambs. Arch Tierz Dummerstorf, 49: 282-288.

MOMANI SHAKER, M., KRIDLI, R. T., ABDULlAH, A. Y., MALINOVÁ, M., SANOGO, S., ŠÁDA, I. and LUKEŠOVÁ D. 2010. Effect of crossbreeding european sheep breeds with awassi sheep on growth efficiency of lambs in Jordan. Agricult. Trop. et Subtrop., 43: 2.

MOUSA-BALABEL, T. M. 2010. The relationship between sheep management and lamb mortality. World Acad. Sci. Eng. Technol., 41: 1201-1206.

NASH, M. L., HUNGERFORD, L. L., NASH, T. G. and ZINN, G. M. 1996. Risk factors for perinatal and postnatal mortality in lambs. Vet. Record, 139(3): 64-67.

PAIM, T., DO, P., DA SILVA, A. F., MARTINS, R. F. S., BORGES, B. O., LIMA, P. DE M. T., CARDOSO, C. C., ESTEVES, G. I. F., LOUVANDINI, H. and MCMANUS, C. 2013. Performance, survivability and carcass traits of crossbred lambs from five paternal breeds with local hair breed Santa Inês ewes. Small Rumin. Res., 112(1-3): 28-34.

PEÑA, F., CANO, T., DOMENECH, V., ALCALDE, M. J., MARTOS, J., GARCIA-MARTINEZ, A. and RODERO, E. 2005. Influence of sex, slaughter weight and carcass weight on "non-carcass" and carcass quality in segureña lambs. Small Rumin. Res., 60(3): 247-254.

PETR, R., DOBEŠ, I. and KUCHTÍK, J. 2009. Evaluation of growth, conformation and fattening in vivo in lambs of selected breeds and crossbreeds [in Czech: Zhodnocení růstu, zmasilosti a protučnění in vivo u jehňat vybraných plemen a kříženců]. Acta Univ. Agric. Silvic. Mendelianae Brun., 57(2): 79-86.

PLUSH, K. J., BRIEN, F. D., HEBART, M. L. and HYND, P. I. 2016. Thermogenesis and physiological maturity in neonatal lambs: A unifying concept in lamb survival. Anim. Prod. Sci., 56(4): 736-745.

PTÁČEK, M., DUCHÁČEK, J., HAKL, J. and FANTOVÁ, M. 2017. Analysis of multivariate relations among birth weight, survivability traits, growth performance, and some important factors in Suffolk lambs. Arch. Anim. Breed., 60(2): 43-50.

PTÁČEK, M., DUCHÁČEK, J., STÁDNÍK, L., BERAN, J. and NĚMEČKOVÁ, D. 2015. Influence of selected factors on growth performance of Suffolk lambs and their crossbreds. Jour. of Centr. Europ. Agricult., 16(1): 188-196.

PTÁČEK, M., ŠTOLC, L., STÁDNÍK, L. and KLUKOVÁ, H. 2013. In vivo assessment of growth traits and meat production in charollais and kent lambs. Sci. Agric. Bohem., 44(1): 10-17.

PTÁČEK, M., ŠTOLC, L., STÁDNÍK, L. and ŠTOLCOVÁ, J. 2011. Influence of selected factors on growth abilities and meat performance indicators in Suffolk and Charollais lambs [in Czech: Vliv vybraných faktorů na růstové schopnosti a ukazatele masné užitkovosti u jehňat plemen suffolk a charollais]. Acta Taurologica, 53(4): 49-61.

RAHIMI, S. M., RAFAT, S. A. and JAFARI, S. 2014. Effects of environmental factors on growth traits in Makuie sheep. Biotechnol. in Anim. Husband., 30(2): 185-192.

RASHIDI, A., MOKHTARI, M. S., JAHANSHAHI, A. S. and ABADI, M. M. 2008. Genetic parameter estimates of pre-weaning growth traits in Kermani sheep. Small Rumin. Res., 74(1-3): 165-171.

RIGGIO, V., FINOCCHIARO, R. and BISHOP, S. C. 2008. Genetic parameters for early lamb survival and growth in Scottish Blackface sheep. J. Anim. Sci., 86(8): 1758-1764. 
SCHREURS, N. M., KENYON, P. R., MUlVANEY, F. J., MOREL, P. C. H., WEST, D. M., and MORRIS, S. T. 2010. Effect of birthweight and birth rank on the survival of single and twin lambs born to ewe lambs. Anim. Prod. Sci., 50(6): 460-464.

SIMEONOV, M., TODOROV, N., NEDELKOV, K., KIRILOV, A. and HARMON, D. L. 2014. Influence of live weight, sex and type of birth on growth and slaughter characteristics in early weaned lambs. Small Rumin. Res., 121(2-3): 188-192.

SUŠIĆ, V., PAVIĆ, V., MIOČ, B., ŠTOKOVIĆ, I. and KABALIN, A. E. 2005. Seasonal variations in lamb birth weight and mortality. Vet Arhiv, 75(5): 375-381.

ŠTOLC, L., PTÁČEK, M., STÁDNÍK, L. and LUX, M. 2011. Effect of selected factors on basic reproduction, growth and carcass traits and meat production in texel sheep. Acta Univ. Agric. Silvic. Mendelianae Brun., 59(5): 247-252.

TASKIN, T., KAYMAKCI, M., SÖNMEZ, R., YILMAZ, M. and BARDAKCIOGLU, H. E. 2012. Genetic and non-genetic parameter estimates for growth traits of sönmez lambs. Vet. Med. Zoot., 60(82): 79-83.

THOMSON, B. C., MUIR, P. D. and SMITH, N. B. 2004. Litter size, lamb survival, birth and twelve week weight in lambs born to cross-bred ewes. Proc. New Zeal. Grassl. Assoc., 66: 233-238.

TURKSON, P. K. and SUALISU, M. 2005. Risk factors for lamb mortality in Sahelian sheep on a breeding station in Ghana. Trop. Anim. Health and Product., 37(1): 49-64.

VOSTRÝ, L. and MILERSKI, M. 2013. Genetic and non-genetic effects influencing lamb survivability in the Czech Republic. Small Rumin. Res., 113(1): 47-54.

WOLFOVÁ, M., WOLF, J. and MILERSKI, M. 2009. Calculating economic values for growth and functional traits in non-dairy sheep. J. Anim. Breed. Genet., 126(6): 480-491.

Contact information

Anežka Málková: malkovaa@ af.czu.cz

Martin Ptáček: ptacekm@af.czu.cz

Luděk Stádník: stadnik@af.czu.cz

Jaromír Ducháček: duchacek@af.czu.cz 